\title{
Development of Research on Treatment Technology for Low-concentration Uranium
}

\author{
NI YueRan ${ }^{1, a}$, GUO Yadan ${ }^{1,2, b, *}$, OUYANG WeiWei ${ }^{1, c}, \quad$ LI Peng ${ }^{1, d}$ \\ ${ }^{1}$ School of Water Resources \& Environmental Engineering, East China Institute of Technology, \\ Nanchang, JiangXi, China, 330013 \\ ${ }^{2}$ State Key Laboratory Breeding Base of Nuclear Resources and Environment, East China Institute \\ of Technology, Nanchang, JiangXi, China, 330013 \\ a qingyueziran@163.com, 'buoyadan88@163.com*, 'cm15717916787@163.com, \\ dlipeng624@126.com
}

Keywords: low-concentration; uranium-bearing waste-water; treatment technology.

\begin{abstract}
Based on analyzing the characteristics of the environment of low concentration uranium, the traditional processing method of low concentration uranium waste-water, such as adsorption method, chemical precipitation, evaporation-enrichment method were summarized. Then the principle, characteristics and scope of the latest processing technology such as Bentonite method, Zero-valent iron, biological adsorption method were summarized, and finally points out that the comprehensive utilization of various methods is an effective way to deal with low concentration uranium waste-water.
\end{abstract}

\section{Introduction}

Uranium is a natural radioactive element, if it entering the body of animals, it still emits rays to stimulate and effect the transformation on the growth of animals and plants, if uranium enters into human bodies it will harm to their health, and lead to infection of other diseases.

Low concentration wastewater contains uranium mines' water and post-treatment process of wastewater discharged from the plant, which also included the addition to the radioactive heavy metal. Far higher than the national emission standards $(0.05 \mathrm{mg} / \mathrm{L})$. Acidic wastewater hexavalent uranium generally forms hexavalent $\left(\mathrm{UO}_{2}{ }^{2+}\right)$ presence, when the uranyl sulfate at $\mathrm{pH}$ is greater than 3 begins strong hydrolysis, when $\mathrm{pH}$ value reaches 5 to 6 can be precipitated completely. Due to the different sources of emissions, the concentration of uranium in water are not the same, tetravalent uranium is easy to become stable complexes with inorganic carbon, and ultimately be precipitation, and soluble hexavalent uranium is better, is not easily to be removed, it refers to the removal of hexavalent uranium and its compounds in the main body of water.

\section{Low Concentration Wastewater Containing Uranium Conventional Processing Techniques}

Similar to other wastewater treatment, the treatment of low concentration of uranium wastewater are intercepting uranium substance as much as possible, direct precipitation or concentration in the water, in order to achieve the effect of purifying water body. This method can be simple divided into chemical form transformation technology and the chemical form does not change, common with adsorption, chemical precipitation, evaporation-enrichment method, extraction, ion exchange method, etc, the advantages and disadvantages of them, such as table 1.

\section{Adsorption method.}

Adsorption treatment of wastewater means the fixation of hazardous substances in the adsorbent surface contact with wastewater and a solid adsorbent, finally the toxic and hazardous substances had been removed in the wastewater, also it is the mass transfer that contaminant transferred from liquid phase to solid phase. Adsorption process mainly based on adsorbent, it has a high selectivity for radionuclides, and not only adsorbed molecules but also adsorbed ions. 


\section{Concentrated by evaporation method.}

Concentrated by evaporation method applies to non-volatile radioactive elements expect few elements such as iodine and tritium, this method could obtain a concentrated radioactive elements in the residual liquid. Impurities also be concentrated by any concentration method and resulting accumulation in the plating tank finally. because it entrained radioactive waste, it should be pretreated, and the method should also concentrate on scaling, explosion, anti-foam and other factors simultaneously.

Extraction Method.

Extraction wastewater treatment principle is separating and removing radioactive contaminants in wastewater by adding a water-insoluble solvent interaction. Nevertheless, wastewater still containing pollutants with high radioactivity after separation, so extraction process is not commonly used in treating uranium-containing wastewater.

\section{Ion exchange.}

Ion exchange means the radioactive ions and other toxic and harmful ions in radioactive waste exchange with the ion from the ion exchangers, finally pollutants had been removed in the wastewater. it is generally believed that Ion exchange method applies to the radioactive waste of the concentration of ions in constant competition is lesser than $1000-1500 \mathrm{mg} / \mathrm{L}$, instead of the radioactive wastewater containing a high concentration of competitive ions.

In conclusion, a variety of traditional processing methods have their advantages and disadvantages, scope of application are also different(see Table 1).

Tab 1 The advantages and disadvantages of the traditional treatment of wastewater with low concentration uranium

\begin{tabular}{|c|c|c|c|}
\hline Approach & Advantages & Disadvantages & Remark \\
\hline $\begin{array}{l}\text { Adsorption } \\
\text { method }\end{array}$ & $\begin{array}{l}\text { Simple process, wart } \\
\text { removal efficiency }\end{array}$ & $\begin{array}{l}\text { Expensive, not suitable } \\
\text { for large amount of } \\
\text { wastewater treatment }\end{array}$ & $\begin{array}{l}\text { Combined with } \\
\text { coagulation } \\
\text { sedimentation, removal } \\
\text { rate reaches up to } 99 \%\end{array}$ \\
\hline $\begin{array}{l}\text { Chemical } \\
\text { precipitation }\end{array}$ & $\begin{array}{l}\text { Low cost, simple } \\
\text { process, strong } \\
\text { resistance to hydraulic } \\
\text { and water impact load }\end{array}$ & $\begin{array}{l}\text { Difficult operation, } \\
\text { effluent concentration } \\
\text { often not up to standard, } \\
\text { have secondary pollution }\end{array}$ & $\begin{array}{l}\text { Commonly used in } \\
\text { mining, metallurgical } \\
\text { wastewater from } \\
\text { factories }\end{array}$ \\
\hline $\begin{array}{l}\text { evaporation-en } \\
\text { richment } \\
\text { method }\end{array}$ & $\begin{array}{l}\text { The method is simple, } \\
\text { reliable and effective, } \\
\text { high removal rate }\end{array}$ & $\begin{array}{l}\text { Cost is higher, } \\
\text { concentrated mud } \\
\text { solidified block } \\
\text { processing }\end{array}$ & $\begin{array}{l}\text { Less applicable to } \\
\text { water, wastewater of } \\
\text { low specific activity }\end{array}$ \\
\hline $\begin{array}{l}\text { Extraction } \\
\text { Method }\end{array}$ & $\begin{array}{l}\text { Effect is good, the } \\
\text { uranium concentration } \\
\text { in water is low }\end{array}$ & $\begin{array}{l}\text { High cost, high residual } \\
\text { radioactive after } \\
\text { extraction }\end{array}$ & Used in pilot stage \\
\hline Ion exchange & $\begin{array}{l}\text { Emergence coefficient } \\
\text { is high, the overall } \\
\text { removal effect is good }\end{array}$ & $\begin{array}{l}\text { High cost, the } \\
\text { regeneration of the ion } \\
\text { exchanger and treatment } \\
\text { more difficult }\end{array}$ & $\begin{array}{l}\text { Applied in industry } \\
\text { production process and } \\
\text { wastewater treatment }\end{array}$ \\
\hline
\end{tabular}

\section{Low Concentrations of Uranium-containing Wastewater Treatment New Technology}

\section{Emulsion liquid membrane separation.}

Emulsion Liquid Membrane separation is a new technology, liquid emulsion membrane can be divided into carriers and non-carriers according to separation mechanism, the process is extracted and back-extracted on both sides of the membrane simultaneously. Including phase-membrane 
phase-external phase system, the separated components from the external phase solution into the membrane phase solution, then moved to the internal phase solution, and concentrated.

Liquid emulsion membrane technology has been fully used in treating uranium-contained wastewater because of simple process, reusable permeate, single-stage separation and high efficiency. Its extraction efficiency is unmatched by solvent extraction, account for the extraction of physical chemical equilibrium limitations, uranium can migrate against the concentration gradient. Kulkarni[1,2] experimentally studied on emulsion liquid membrane method of uranium extraction, emulsion liquid membrane made of a composite component can concentrate uranium ions 6 times, and uranium ion content in the raffinate can reduce to $50 \mathrm{mg} / \mathrm{L}$ through a two-stage countercurrent extraction for the initial concentration of $600 \mathrm{mg} / \mathrm{L}$ of uranium-contained wastewater, The main disadvantage of Emulsion Liquid Membrane is that the separation system have to go through three phases, and there are stringent requirements about stability and extraction of emulsion and emulsion breaking technology, especially it can not meet the actual large scale industrial applications in terms of stability of the film.

\section{Bentonite processing uranium-contained wastewater.}

Bentonite is a montmorillonite-based clay minerals. Its main mechanism of wastewater treatment is the adsorption which divided into physical adsorption and exchange adsorption. Physical adsorption is caused by intermolecular forces(Van der Waals forces), and exchange adsorption caused by static electricity and Van der Waals forces.

There are many methods of bentonite modification, such as acidification, oxidation, reduction, melting method and hydrogenation method, in which acidification(sulfuric acid or hydrochloric acid treatment) is more simple. Modified bentonite has excellent adsorption properties, and it can enrich, remove radioactive waste. $\mathrm{pH}$ has great influence on the removal efficiency of acidic bentonite treatment to heavy metal ions if $\mathrm{pH}$ is high, not only acidic bentonite adsorption and exchange happened, but also precipitation, and removal rate is high.

\section{Zero-valent Iron in the Application of Uranium-contained Wastewater.}

Iron is active in chemistry, with reduction, adsorption coagulation and micro electrolysis. Experiments about ZVI treatment to AMD made by Richard and others show that ZVI can remove heavy metal ions effectively. Iron can also remove nitrate in acidic in-situ leaching of uranium in groundwater, when uranium leaching groundwater $\mathrm{pH}$ of 1.1, but there has little relevant reports about the basic theory research.

1) reduction

ZVI electronegativity is larger and electrode potential of $\mathrm{E}^{0}\left(\mathrm{Fe}^{2+} / \mathrm{Fe}^{0}\right)=-0.44 \mathrm{~V}$, when there is a strong oxidant solution, $\mathrm{Fe}_{2}{ }^{2+}$ can be further oxidized to $\mathrm{Fe}^{3+}$, thus $\mathrm{Fe}^{0}$ is a strong reducing agent, $\mathrm{UO}_{2}{ }^{2+}$ reduction reaction in the electrochemical dissolution product through transfer of electron in the ZVI surface. When there is a low concentration of the ZVI and dissolution product in systems, $\mathrm{UO}_{2}{ }^{2+}$ is mainly reduced to $\mathrm{U}(\mathrm{IV})$ and precipitated onto the iron surface. The main reaction is:

$$
\mathrm{Fe}^{0} \longrightarrow \mathrm{Fe}^{2+}+2 \mathrm{e}^{-}
$$

$$
\mathrm{UO}_{2}{ }^{2+}+4 \mathrm{H}^{+}+2 \mathrm{e}^{-} \longrightarrow \mathrm{U}(\mathrm{IV})+2 \mathrm{H}_{2} \mathrm{O}
$$

Abdelouas et al[3] studied on the feasibility of reduce $\mathrm{U}(\mathrm{VI})$ with $\mathrm{ZVI}\left(\mathrm{Fe}^{0}\right)$ material. At a certain temperature limit, they conducted a series of experiments with the iron and U(VI) concentrations were $0.25 \mathrm{mg} / \mathrm{L}$ and $9.3 \mathrm{mg} / \mathrm{L}$ solution and found that the main mechanism to remove uranium from the solution is $\mathrm{Fe}^{0}$ reduced $\mathrm{U}(\mathrm{VI})$ to $\mathrm{U}(\mathrm{IV})$, and the reaction of its occurrence as follows:

$$
\mathrm{Fe}^{0}+\mathrm{UO}_{2}{ }^{2+} \longrightarrow \mathrm{Fe}^{2+}+\mathrm{UO}_{2}
$$

2)Coagulation adsorption

Under acid condition, ZVI processing uranium wastewater will produce a large number of bivalent iron and ferric iron.

$$
\text { Divalent iron: } \mathrm{Fe}^{2+}+2 \mathrm{OH}^{-} \longrightarrow \mathrm{Fe}(\mathrm{OH})_{2}(\mathrm{~s})
$$


Ferric: $\mathrm{Fe}^{3+}+3 \mathrm{OH}^{-} \longrightarrow \mathrm{Fe}(\mathrm{OH})_{3}(\mathrm{~s})$

When adjusted to an alkaline $\mathrm{pH}$, and produce oxygen, $\mathrm{Fe}(\mathrm{OH})_{2}$ and $\mathrm{Fe}(\mathrm{OH})_{3}$ will form a precipitate, which $\mathrm{Fe}(\mathrm{OH})_{2}$ is a colloid flocculant, and it has good adsorption capacity of uranium ion in water. Gu et al[4] using ZVI precipitate U(VI) In the removal of uranium in the groundwater. The Study compared the ZVI and several adsorbent materials for removal of uranium in groundwater, and showed that ZVI filler is more effective than other adsorbents such as peat, iron oxide for removal of $U(V I)$ from aqueous solutions. When the initial concentration of uranium up to $18 \mathrm{~g} / \mathrm{L}$, almost $100 \%$ of the uranium can be removed by ZVI.

3) Micro-electrolysis

The iron has low potential, and is easy to constitute corrosion cell in the water, when it used as an anode, the hydrogen ions have reduction reaction at carbon which used as the cathode in the iron impurities, and create hydrogen, so that the reactor effluent $\mathrm{pH}$ value increased, heavy metal ions reduction reaction at the cathode will generate elemental metals and be adsorbed or trapped in the reactor, at this time the iron as an anode has Oxidation reaction in the coagulation and generate $\mathrm{Fe}^{2+}$, $\mathrm{Fe}^{3+}$, so that coagulation can be successful to ensure the effect of wastewater treatment. ZVI treatment of uranium-contained wastewater is a comprehensive method of reduction, coagulation adsorption and micro-electrolysis.

Biological assay.

Biological assay means using the chemical structure and composition characteristics of some of the organisms to absorb metal ions dissolved in water, and then through the solid-liquid phase separation to remove the metal ions in the aqueous solution. According to the degree of cell-dependent metabolism, biological adsorption mechanism can be divided into dependent metabolic type(living organisms) and independent metabolic type(dead organisms). Polikarpov has pointed out that marine organisms can accumulate radionuclides through its direct absorption from seawater. The main factors affecting the biological uranium adsorption is $\mathrm{pH}$, bacteria pretreatment, coexisting ions and metallic early concentration. Beer yeast adsorption of uranium primarily depends on the $\mathrm{pH}$, when the $\mathrm{pH}$ is 4.0, uranium exists as the form of $\mathrm{UO}_{2}(\mathrm{OH})^{+},\left(\mathrm{UO}_{2}\right)_{3}(\mathrm{OH})_{5}{ }^{+},\left(\mathrm{UO}_{2}\right)_{2}(\mathrm{OH})_{2}{ }^{2+}$, have the maximum amount of adsorption; $\mathrm{pH}$ value 2.6, only the presence of $\mathrm{UO}_{2}{ }^{2+}$, the adsorption amount becomes small. Temperature and particle size also affect the adsorption of biological adsorption.

Algae or fungi uranium ore processing waste water, can make the uranium content reduced to $5.0 \mathrm{mg} / \mathrm{L} .[5,6]$ As early as 1972, CHIU found fungal cells have uranium enrichment capabilities. Early 1980s, Tsezos and Volesky used biological material to enrich uranium and got the US and Canadian patents; Strandbeg treated nuclear power plant wastewater in Oak Ridge National Laboratory by bacterial and fungal biomass method, it can extracted $90 \%$ of the uranium within hours, and in industry can be repeated use.

On wastewater containing uranium, the above processing techniques have advantages and disadvantages and scope of application(see Table 2). 
Tab. 2 The advantages and disadvantages of the latest treatment method of low concentration uranium wastewater

\begin{tabular}{|c|c|c|c|}
\hline Approach & advantages & disadvantages & Scope \\
\hline $\begin{array}{l}\text { Membrane } \\
\text { emulsificatio } \\
\mathrm{n}\end{array}$ & $\begin{array}{l}\text { Process is simple, high } \\
\text { processing quality, } \\
\text { automation }\end{array}$ & $\begin{array}{l}\text { Expensive, easy to scale } \\
\text { in some cases, the } \\
\text { impact of many factors }\end{array}$ & Laboratory stage \\
\hline $\begin{array}{l}\text { Bentonite } \\
\text { method }\end{array}$ & $\begin{array}{l}\text { High removal efficiency, } \\
\text { strong adsorption } \\
\text { capacity }\end{array}$ & Selectivity & $\begin{array}{l}\text { Radioactive waste } \\
\text { treatment }\end{array}$ \\
\hline $\begin{array}{l}\text { Zero-valent } \\
\text { iron method }\end{array}$ & $\begin{array}{l}\text { High efficiency, simple } \\
\text { process, can handle a } \\
\text { variety of toxic pollutants } \\
\text { simultaneously }\end{array}$ & $\begin{array}{l}\text { Reaction influence } \\
\text { factors, hard to control }\end{array}$ & $\begin{array}{l}\text { Remedies polluted } \\
\text { water from uranium } \\
\text { mines and tailing } \\
\text { piles, sewage } \\
\text { treatment }\end{array}$ \\
\hline $\begin{array}{l}\text { Biological } \\
\text { Adsorption } \\
\text { method }\end{array}$ & $\begin{array}{l}\text { Small investment, simple } \\
\text { equipment, adsorption } \\
\text { capacity and good } \\
\text { selectivity }\end{array}$ & $\begin{array}{l}\text { Partial purification of } \\
\text { contaminated } \\
\text { groundwater, surface } \\
\text { water and lake }\end{array}$ & $\begin{array}{l}\text { Partial purification of } \\
\text { contaminated } \\
\text { groundwater, surface } \\
\text { water and lake }\end{array}$ \\
\hline
\end{tabular}

\section{Summary}

In conclusion, the majority of releases to the environment is low concentration uranium-contained waste-water for nuclear fuel cycle or other reasons. Currently these new technologies can solve the secondary pollution caused by large sludge after conventional purification processes, and the limitations of water and many other issues. Bentonite have extensive application prospects and will replace the traditional adsorbent as the main material used in industrial production and waste-water treatment for its wide range, low prices, abundant reserves, etc; ZVL began to processing uranium mine waste-water for its high efficiency and simple process. However the single new treatment technologies have low processing efficiency and price is very expensive. So in practical application of engineering, it's important to select one or above several methods in combination to achieve the desired treatment effect according to factors of water waste, the content of uranium, other coexisting ions and $\mathrm{pH}$ value of waste-water, then create favorable conditions for the final disposal of radioactive waste.

\section{Acknowledgement}

This work was supported by Jiangxi province Training Programs of Innovation and Entrepreneurship for Undergraduates (2310400160;2310400166)

\section{References}

[1] PS Kulkarni. Recovery of uranium(VI) from acidic wastes using tri-n-octylphosphine oxide and sodium carbonate based liquid membranes[J]. Chemical Engineering Journal 2003, 92(1-3): 209-214.

[2] PS Kulkarni, S Mukhopadhyay, MP Bellary, et al. Studies on membrane stability and recovery of uranium(VI) from aqueous solutions using a liquid emulsion membrane process[J]. Hydrometallurgy, 2002, 64(1): 49-58.

[3] A Abdelouas, W Lutze , E Nuttall, et al. Remediation of U(VI)-contaminated water using zero-valent iron[J]. Comptes Rendus De Lacademie Des Sciences, 1999, 328: 315-319.

[4] B Gu, L Liang, MJ Dickey, et al. Reductive Precipitation of Uranium(VI) by Zero-Valent Iron[J]. Environ.sci.technol, 1998, 32(21): 3366-3373. 
[5] L.Bengtsson, B.Johansson. Studies on the Biosorption of Uranium by Talaromyces emersonii CBS 814. 70 Biomass[J]. Applied Microbiology Biotechnology, 1995, 42: 807-811.

[6] N.Ferris, P.Myers-Keith. Biosorption of Uranium and Lead by Streptomyces Longwoodensis[J]. Biotechnology\&Bioengineering, 1986, 24: 385-410. 